\title{
分かりやすいコトバが日本を救う*
}

\section{望月 護**}

Turning the specialists' terms into the words of common sense will rejuvenate the strength of Japan / Mamoru MOTIZUKI

Key words: word

\section{1. 今なぜドラッカーなのか}

現在は，過去の常識や価值観がまったく通用しなくなり 大きな混乱が起こっている．その理由をドラッカーは 200 年間続いたモノ不足 (工業) 社会が終わり, 次の社会へ向 かっている転換が起こっているからだという。過去の常識 や価值観が通用しなくなるような社会が転換する時代は初 めてではなく, 過去にも起こっているから, 過去に起こっ たことを学ぶことによって打開策が分かるのである。

今年 90 歳を越えるドラッカーはオーストリアで生まれ, 二度の世界大戦を経験し，ナチスの台頭するヨーロッパか らアメリカへ渡り，価值観のまったく異なる二つの時代を 生きてきた。

ドラッカーは経営学者, 社会生態学者として知られる が，経済学者でもなければ社会学者でもない. 彼が追求し たテーマはあえていえば経世済民である，経世済民とはみ んなが仲良く豊かに暮せるための実践的な方法論である.

問題を解決するためには総合力が必要だが, 近代に入っ てから専門分化が進み, さまざまな要素が入り組んだ複雑 な現実の問題を総合的に解決することが難しくなってし まった。

すべての企業がコストダウンに取り組めば，全体として は不景気になってみんなを困らせるし，すべての工程が在 庫を抱えれば，全体にとっては膨大なムダが生まれる．部 分的に見ると一見正しく見えることも全体から見れば間 違っていることが多い. しかし全体を捉えることはやさし いことではない，全体を全体としてとらえるためには，幅

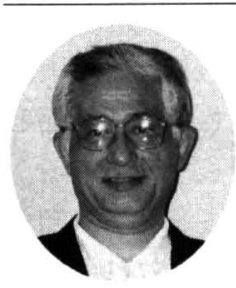

* 原稿受付 平成 13 年 6 月 13 日

** 東京都三鷹市下連雀 6-9-17

1964 年慶応義塾大学経済学部卒. 大日本印刷 株式会社入社，市谷営業第二本部長，ダイッ ク常務取締役, 大日本運輸取締役管理部長など を経て執筆活動に入る.

著書：ト゚ラッカーの筤言 日本はよみがえる (祥伝社), ドラッカーと福沢諭吉・二人の巨人 に学ぶ日本経済転換のとき（祥伝社）
広い視野と時代を見通す見識が必要である。

リエンジニアリング (原材料の調達から扔客の手に渡る までの工程を見直して無駄を省こうという考え方）やサプ ライ・チェーン・マネジメント (メーカーと流通業者が提 携して製品が工場を出荷してからお客の手に渡るまでの工 程を見直して無駄を省こうという考元方）というものの考 え方が生まれてきたのは, これまで生産性を上げてきた夕 テ割分業が行き詰まったからである，そこで再び工程全体 からしくみを見直す発想が生まれてきたのである。

ドラッカーは, 部分でなく全体でものごとを捉えて, 大 きな責任を負っている世界中の組織のリーダーにものの見 方と考え方を指導している先生である.リーダーが誤った 判断を行わないように，世界で起きている変化をよく見て 分析し，警鐘を鳴らして教えてくれるのである。ゼネラ ル・エレクトリックを再生させたジャック・ウェルチの組 織革新の指導原理はドラッカーの著作である. 国有企業の 民営化に挑んだサッチャー首相の教科書となったのはド ラッカーが著した『断絶の時代』である.

\section{2. 激動の正体}

経済が長く停滞しているため閉塞感と絶望感が覆ってい る.いったい何がこのような閉塞感を起こしているのだろ うか.もちろん銀行の不良債権処理が終わっていないと いった問題もあるが，停滞の原因は 3 つあり，世界中で同 じことが起こっているのである.

\section{1 作り過ぎによるモノ余り}

終戦直後農民は就業人口の 50 \%を占めていたが今では $5 \%$ しかいない. 工員は昭和 52 年の $35 \%$ をピークにそ の後は減りつづけ, 今では $28 \%$ 程度になった. 農民も工 員も大幅に減り, 現在も減り続けている. 肉体労働者の代 わりに増加しているのは, 専門知識を使って働く専門家で ある。

生産工場の現場を放映するテレビ画面からはほとんど人 は見あたらない，ロボットの姿ばかりが映る。これは中小 
工場でも同じである．工場内に肉体作業はなく，監視や検 查に人がいるだけでほとんどの仕事が自動化されている。

40 年前に多色印刷の主力は 2 色機で 1 時間に 3000 枚 刷っていた. 現在では 8 色輪転機が 1 時間に 12000 枚 刷っている. 40 年間で 16 倍になったのである。しかもイ ンキを練る人間もいなければ紙を積む人間もいない，1人 あたりの生産性は奏に 30 倍以上になった，同じことがあ らゆる業種で起こり, 生産能力が過㮃になってつくり過ぎ が起こっているのである.

生産能力が上がってモノ余りになった結果, 在庫品が ディスカウントストアや 100 円ショップに流れている. 最 近まで高成長を謳歌していたパソコンも携带電話も，今年 に入ってから作り過ぎによって大量の在庫を抱えている. 「IT 産業は適正な在庫をつかんでいるから在庫過剰による 不況がない」と豪語して躍進を続けてきたシスコシステム ズが，在庫の山を抱えて苦しんでいる。

スーパーは 4 万点, コンビニは 3000 点の品目を陳列し ているが，普通の家庭では日用の買物は 150 品目もあれば 8 割は揃ってしまう。つまり 150 品目以外の商品はどうで も良い商品（コモディティ商品）だから, 特徵がなければ 売れない. 売れ筋に絶えず目を光らせているセブンイレブ ンにしても，1 カ月に 1 つも売れない商品が 500 もあると いうことである.

\section{2 グローバル化による世界競争}

ユニクロは中国で生産してカジュアル衣料の価格を 3 分 の 1 に下げた. 日本マクドナルドは牛肉を為替の安い時に 予約して平日ハンバーガー半額セールを実施した。ユニク ロの影響はアパレル業界だけでなく，タオル業界，下着， 寝具，さらにスーパー，専門店，卸にまでおよび，日本マ クドナルドの影響はロッテリアやモスバーガーだけでな く, コンビニの抬弁当, 牛井チェーンにまで及んでいる。 為替と無縁の業界もライバル企業が為替をたくみに使って 価格を下げるから為替の影響を受けざるを得ない。

ブラウン管テレビを国内で作っているメーカーは現在で は松下とソニーなどほんの数社で，ほとんどのメーカーは 中国で作っている.

同じことが学校や病院でも起こる.アメリカの研究者の レポートによれば，大学進学率が50\%を超えると大学は グローバル化するという。

官僚の不祥事が次々に暴かれはじめたのは，国内経済が グローバル経済に変わったからである。許認可, 行政指 導，規制が通用しなくなり，官僚が急速に力を失ったため である。

\subsection{IT (情報) 革命}

パソコンが普及してもインターネットが出現しても，従 来行っていた仕事が便利になっただけで新しいものが生ま れたわけではない.ところがインターネットを使って取引 を始めるようになったとたんに，市場は一挙に世界に広
がってしまった，世界中から買い手を探したり売り手を探 すことが出来るようになった。遅かれ早かれローカルな市 場はなくなることは確実である。

ドラッカーは，「産業革命は蒸気機関によって始まった が，50 年後に鉄道が出現してから社会が一変した．IT 革 命もコンピュータによって始まったが, eコマースが出現 したことによって社会が一変する」といっている。

鉄道が登場して栄えた産業は鉄道を走らせた会社でもな く，鉄道を建設する会社でもなかった，栄えたのは鉄道網 を利用してモノを大量に菜早く安く運んだ会社である。 フォードの作ったクルマ, カーネギーの売った鉄鋼, ロッ クフェラーの売った石油はどこよりも安かった。

ということは，これから伸びる産業を予測してみると， コンピュータを作る産業でもなく通信を接続する産業でも ないということである.コンピュータと通信網を使って素 早く安く取引を行う企業が栄える企業となる。

物流業のフェデラル・エクスプレスは，IT（情報技術） を使って貨物が今どこにあるか拉客が自分で追跡できるだ けでなく，お客が積みこみ地と積み下ろし地を自分で設定 すればコストがいくらか計算することが出来るシステムを 提供してお客をつかんでいる．創立して 30 年，71年（昭 和 46 年）創業の若い企業だが，企業の物流管理を手がけ て躍進した．1日 330 万個の荷物を扱い，667機の航空機 を持ち, 20 万人の従業員を擁して世界中に荷物を配送し ている.

パソコンメーカーのデルは，ITを使って招客から直接 注文を受けるシステムを開発して在庫を減らし，価格を大 幅に下げてお客をつかんでいる。

旭川の住宅業者は ITを使って価格を 3 割下げた。パソ コン画面上に立体的に見られる仮想展示場を用意してお客 に見せ，見積りからローンの相談までメールでやり取りし て営業経費を大幅に下げたのだ。

すかいらーくはホームページを使って購入したい食材と 量を提示して業者を募集した。現在では過去に取引のな かった企業の落札が 3 割を占め, 仕入れコストを大幅に下 げている.

\section{3. 異質の知識の結びつきが社会を発展させる}

このような激動の中でどうすれば生き残って，どうすれ ば社会に貢献することが出来るのだろうか，その答えはイ ノベーションつまり時代遅れになった製品や事業や仕事の 方法を，時代に合った製品や事業や仕事の方法に新陳代謝 することにある。

70 年前に経済学者シュムペーターは画期的な新製品や 新規事業は「新結合」によって生まれるといった。シュム ペーターはイノベーションのことを，発明とか，新製品と か，新規事業と言わずに「新結合」と表現したのである. いかに画期的な技術を発明しようとも，扔客をつくる知識 や力ネを集める知識と結びつけることが出来なければ，社 会を発展させる力になり得ないからだ。 
画期的な新規事業や新製品（イノベーション）はゼロか ら開発されたものではない，異なる分野の知識が二つ以上 結びついた時に生まれている。

エジソンが発明した白熱電灯はゼロから開発したもので はない.それまで開発された電灯は数秒間しかつかなかつ たが，フィラメントを改良することによって数百時間もつ 電球に変えたのである.

\section{4. 儲かる新製品は異なる知識の組合せによって 生まれている}

利益を上げている新製品はゼロから開発されたものでは なく，すでに存在する知識と異なる知識を結びつけること によって開発されている. 先端的企業と言われているソ ニーにしてもゼロから開発した新製品はほとんどない。

$\mathrm{AT} \& \mathrm{~T}$ が開発したトランジスタの基礎技術は基本原 理であって，そのままではせいぜい補聴器ぐらいしか作れ なかった。ソニーはトランジスタの基礎技術を他のさまざ まな知識と結びつけることによって，小型で軽量で值段の 安いトランジスタラジオをつくったのである.

ウォークマンにしてもソニーが新しく開発した技術はど こにもない.いつでもどこでも好きな音楽を一人で楽しめ る小型で便利な録音再生機があれば面白いと考えついたア イデアが，世界中に新しいお客をつくったのである。

トリニトロンテレビは，シャドーマスク方式とは異なる 技術のテレビである。一般的にトリニトロンテレビはソ ニーがゼロから開発した技術だと思われているが，ソニー がゼロから開発した技術ではない.アメリカで開発された クロマトロンと呼ばれる特許をソニーが買い取って，テレ ビに応用したのである。他社が量産化しやすいシャドーマ スク方式のブラウン管を採用している中で，ソニーは高輝 度で精細な画像が得られるトリニトロン方式のブラウン管 の開発に挑戦し， 68 年（昭和 43 年）に成功したのであ る.

ビル・ゲイツにしてもゼロから新しい科学知識を開発し たわけではない、すでに存在していたさまざまな知識を結 びつけることによって誰でも手軽にコンピュータを使える 基盤をつくったのだ.しかし知識の結びつけ方が誰も思い つかないほど型破りだったのである。

知識の結びつけ方が型破りであるほど，付加価值の高い 画期的な新規事業や新製品（イノベーション）が生まれて いるのである。

\section{5. 異質の知識をどうやって結びつけるか}

前述したように利益を上げる新製品，新サービス，新し い提案，新規事業を開発するためには，異なる分野のさま ざまな専門家の知識を結びつけることが必要である。とい うことは，さまざまな専門家の知識を交流させることが付 加価値を生み出すということである。したがって生まれも 違えば育ちも違い個性も違うさまざまな専門家を集めて, 共通の目的に向かわせる仕事が非常に重要になる，つまり
さまざまな知識を持ったメンバーを, 共通の目的に向かわ せる住事が必要になるのである。

日本やアメリカなどのように賃金の高い先進国の企業が 生き残る道は, 知識（ノウハウやアイデア）を基盤にし て, みんなが欲しがるような魅力のある新製品, 新サービ ス，新しい提案をどしどし開発することである．国内では 军を 500 円で作ることも出来なければ，みかんの缶詰を 100 円でつくることも出来ない.

魅力のある売り物を開発すれば，ロイヤリ.ティ収入（権 利の使用料)，ライセンス収入 (ライセンスの使用料), サービス手数料による収入，著作権収入，技術指導料，特 許料, コンサルタント料などの知的財産で稼ぐことが出来 るのである。

\section{6. 相手に通じるコトバをつかう}

現在の社会は異なる分野の專門家の知識を結びつけるこ とがなにより必要である。ということは專門家が専門以外 の人間に専門分野の知識を伝えることが必要だということ である、これまでわれわれは，職場以外の場所で仕事の話 をすることを，野暮なことだと否定してきたが，ドラッ カーはそれでは社会が発展しないという。

つまり専門以外の人間に通じるコトバを使って, 話し, 文章を書くことが付加価値を生み出すという認識が必要な のである。科学者がいかに優れた技術を開発しようとも， 政治家や起業家や営業（マーケティング）の専門家に通じ なければ, 知識は活用されず，宝の持ち腐れに終わってし まう. 専門以外の人間が別の知識と結びつけてはじめて， 新しい製品や新しい事業が生まれて社会が発展するのであ る.

ドラッカーは，第二次大戦後分かりやすいことはレベル が低いと考えるような風潮になったことを嘆かわしいと次 のように述べている。

「社会学の巨人といわれたドイツのマックス・ウェー バーは偉大な学者だったが，単純明快に分かりやすく一般 の人が分かるように新聞や雑誌にものを書いたから，当時 の人たちの考え方が進歩したのである、難しい話を世の中 一般の人のためにやさしく書くことが，知識を持つ人間の 責任である.」

福沢諭吉は「文章は読み手の立場にたって書け」と教え ている．福沢諭吉の著作がベストセラーになったのはなん といっても分かりやすかったからである. 分かりやすい文 章を書くために福沢は寄席に行って日常的に使われている コトバの研究をしていたと言う。明治時代初めの日本人に 意味を伝えるために，バターをあえて味噌と超訳したのは 福沢諭吉である。

明治以降，日本が急速に発展を始めた大きな理由は，あ らゆる分野で翻訳が行われたからである，他国では英語や フランス語で行われている高校や大学の授業つまり西洋か ら入ってきた知識を, 普通の日本人が日本語で学ぶことが 出来たからである. 


\section{7. 意味を伝えることが新しい付加価値を生む}

年々コトバの数が増え，しかもジュリアス・シーザーが ユリウス・カエサルに変わったように，いつのまにかコト バが変わってしまうから専門外の人間は困ってしまうので ある．技術系の方には笑われるだろうが，私がマイクロ メーターとミクロメーターが同じ意味の英語読みとドイツ 語読みだと知ったのは最近である。私の勤めていた会社で は荷物に貼るラベルは工場によって違うコトバが使われて いた．荷札ラベル，製品ラベル，現品票，PD（フェディ カル・デストリビューション) ラベルである。それでもモ ノを表すコトバは何とか通じるが，ものの考元方（概念） を伝える場合は別である。環境問題に取り組んでいる人の 話では，アメリカには「もったいない」というものの考え 方がないため，「もったいない」というコトバの意味を英 語で伝えるためには, 2 分の 1 ページほどのセンテンスが 必要になるとのことである.

いかに優れた意見, 優れた論文であっても意味が通じな
ければ価值を生むことはできない。これからわれわれは仲 間内で使っているコトバが，専門外の人間に正しく理解さ れているかどうか確認することが必要である．また意味の 分からないコトバについては，恥を恐れずに意味が分かる まで聞きただすことも必要である。長年仕事をしてきて分 かったことは, 回りくどい言い回し, 総論だけで具体性を 欠くコトバ，きれいごとを並べた美辞麗句には，まったく 違う意味が隠されていることが多いので注意することが必 要である.

専門家の研究していることが専門外の人間に理解される ことによって，思いがけない分野から新しい協力者やパー トナーが現れて，予想もしなかったヒット商品が生まれた り，思いつかないアイデアを手にいれることが出来るかも しれないのである.

日本の社会には高学歴で知識レベルの高い人材が多数存 在しているから，知識が資源となる時代にあっては，日本 は資源大国だと確信している. 